\title{
Bireyselleştirilmiş eğitim programı hakkında öğretmen görüşlerinin okul sosyal hizmeti perspektifinden değerlendirilmesi
}

\section{Evaluation of teachers' opinions on the individualized education program (IEP) from the school social work perspective}

\author{
Ali Fuat Ersoy ${ }^{1}$, Eda Sancar ${ }^{2}$ ve Meral Şener ${ }^{3}$ \\ ${ }^{1}$ Prof. Dr., Karabük Üniversitesi/IİBF, Sosyal Hizmet Böl., alifuatersoy@karabuk.edu.tr, ORCID: https://orcid.org/0000-0001-7665-6741 \\ ${ }^{2}$ YL Ögrencisi, Karabük Ün./Lisansüstü Eğitim Enstitüsü, edasncar.78@gmail.com, ORCID: https://orcid.org/0000-0002-2002-0696 \\ ${ }^{3} Y L$ Ögrencisi, Karabük Ün./Lisansüstü Ĕgitim Enstitüsü, meral_senerr@hotmail.com, ORCID: https://orcid.org/0000-0002-4176-3405
}

\begin{tabular}{|c|c|}
\hline Makale Bilgisi & $\ddot{O} z$ \\
\hline $\begin{array}{l}\text { Araştırma Makalesi } \\
\text { Gönderilme: } 24 \text { Mayıs } 2021 \\
\text { Düzeltme: } 29 \text { Eylül } 2021 \\
\text { Kabul: } 2 \text { Ekim } 2021 \\
\text { Anahtar kelimeler: } \\
\text { Bireyselleştirilmiş eğitim } \\
\text { programı, } \\
\text { Okul sosyal hizmeti, } \\
\text { Öğretmen, } \\
\text { Öğretmen görüşü }\end{array}$ & 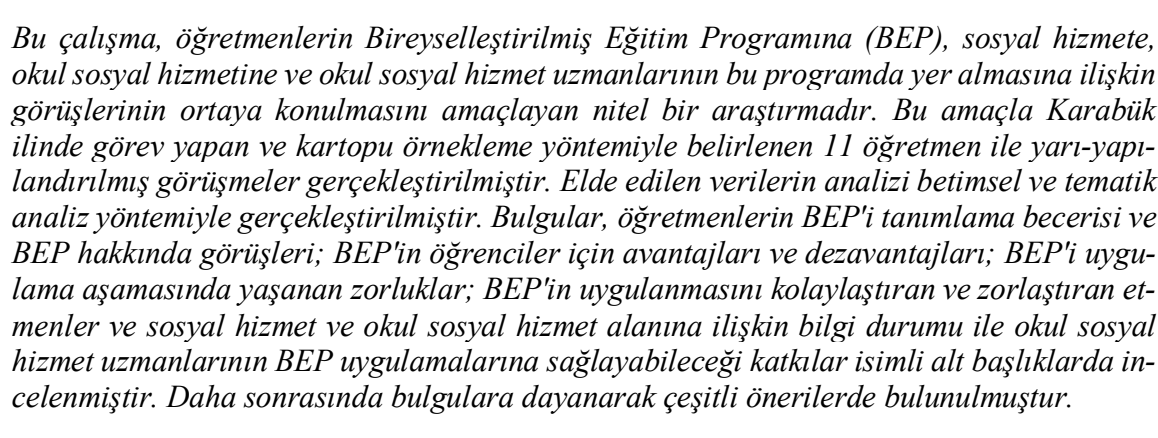 \\
\hline Article Info & Abstract \\
\hline $\begin{array}{l}\text { Research Article } \\
\text { Received:24 May } 2021 \\
\text { Revised: } 29 \text { September } 2021 \\
\text { Accepted: } 2 \text { October } 2021\end{array}$ & $\begin{array}{l}\text { This study is a qualitative research that aims to reveal teachers' opinions on Individualized } \\
\text { Education Program (IEP), social work, school social work and school social workers' par- } \\
\text { ticipation in this program. For this purpose, semi-structured interviews were carried out } \\
\text { with } 11 \text { teachers working in the province in Karabük who were determined by snowball } \\
\text { sampling method. The analysis of the obtained data was carried out by descriptive and the- } \\
\text { matic analvsis method. The findings were examined in subheadings called teachers' ability }\end{array}$ \\
\hline $\begin{array}{l}\text { Keywords: } \\
\text { Individualized education pro- } \\
\text { gram, } \\
\text { School social work, } \\
\text { Teacher, } \\
\text { Teacher opinion }\end{array}$ & $\begin{array}{l}\text { to define IEP and their opinions on IEP; IEP's advantages and disadvantages for students; } \\
\text { difficulties experienced during the applying of IEP; factors that facilitate and complicate } \\
\text { the applying of IEP, the state of knowledge about social work and school social work, and } \\
\text { the contributions that school social workers can make to IEP applications. Afterwards, } \\
\text { various suggestions were made based on the findings. }\end{array}$ \\
\hline
\end{tabular}

\section{Giriş}

Her birey fiziksel yapı, zekâ düzeyi, yetenek, duygu ve düşünce açısından akranlarıyla aynı özellikleri taşımamaktadır. Toplumun her kesiminde karşılaştı̆̆ımız farklı sebeplerden yetersizliği olan bireyler de tüm bireyler gibi eğitim hakkına sahiptir. Bilişsel, fiziksel, sosyal ve duygusal gelişim olarak akranlarından farklı özellikler gösteren ve destek eğitimine ihtiyaç duyan bireyler özel gereksinimli bireyler olarak tanımlanmaktadır. Eğitimin bireysel farklılıklar dâhilinde düzenlenmesi ve bu farklılıklara göre yapılandırılması için özel eğitime ihtiyaç vardır. Özel eğitim, bireylerin eğitim ve sosyal ihtiyaçlarının karşılanması için özel olarak yetiştirilen personeller, geliştirilen

\footnotetext{
* Bu araştırma T.C. Karabük Üniversitesi Sosyal ve Beşeri Bilimler Etik Kurulunun 09.04.2021 tarih ve 2021/04-08 kararı ile etik açından uygun bulunmuştur. Tüm sorumluluk yazarına aittir.
}

Kaynak göster: Ersoy, A.F.. Sancar, E. \& Şener, M. (2021). Bireyselleştirilmiş eğitim programı hakkında öğretmen görüşlerinin okul sosyal hizmeti perspektifinden değerlendirilmesi. International Journal of Social Sciences and Education Research, 7 (4), 337-352. DOI: https://doi.org/10.24289/ijsser.942244 
eğitim programları, belirli yöntemler ile bireyin yeterliliklerine ve gelişim özelliklerine göre uygun bir ortamda sürdürülen eğitimdir. Özel eğitim, engelli çocuklar için mevcut eğitim sistemini tanımlamak amacıyla kullanılan geniş bir terimdir. Özel gereksinimi olan öğrenciler için erken müdahale ve özel eğitim hizmetleri ile firsat eşitliğinin sağlanması amaçlanmaktadır (Siegel, 2005; Avcıoğlu, 2011; MEB, 2014; Yılmaz ve Batu, 2016; Tekin Ersan ve Ata, 2017).

Aynı engele sahip öğrencilerin farklı ihtiyaçları olabileceğinden okullar her öğrencinin özel ihtiyaçlarına hitap etmek amacıyla öğrencilerin eğitimini bireyselleştirmelidir. Özel eğitim gereksinimi olan birey için geliştirilen eğitim programlarından biri olan Bireyselleştirilmiş Eğitim Programı (BEP), birey için sağlanacak eğitimin yerinin, zamanının, süresinin ve kim tarafından uygulanacağının gösterildiği eğitim alan ile eğitim veren arasındaki bir sözleşmedir. BEP'ler aynı zamanda özel gereksinimli öğrencilerin eğitimlerinin yönetilmesi ve izlenmesi amacına yönelik kullanılan raporlaştırılmış bir dokümandır (Kargın, 2007; Powers, Swick ve Cherry, 2017; Yazıcıoğlu, 2019). Okul sosyal hizmet uzmanları BEP'in yürütülmesini sağlamada önemli rol üstlenen ve BEP ekibinin içerisinde yer alan önemli meslek elemanlarıdır (Raines ve Dibble, 2017). Ancak ülkemizde BEP Geliştirme Biriminde okul sosyal hizmet uzmanları aktif rol almamaktadır (ÖEHY, 2018, Md. 47). Tüm bunlardan hareketle bu çalışmanın amacı öğretmenlerin BEP'e yönelik görüşlerini okul sosyal hizmeti perspektifi ile değerlendirmek ve okul sosyal hizmet uzmanlarının bu programda yer alması ile üstlenebileceği rollere yönelik öğretmen görüşlerine yer vermektir.

\section{Literatür}

BEP, uygun bir eğitim hakkını detaylandıran, özel olarak tasarlanmış öğretimi gerçekleştirmek için gereken önlemleri belirleyen bir programdır. Özel eğitim öğrencisinin benzersiz ihtiyaçlarını karşılamak için geliştirilen ve özel eğitim hizmetleri sağlama planının yazılı bir ifadesi olan BEP'ler öğrencinin mevcut eğitim performansı seviyelerini, hem genel hem de özel eğitim sınıfları için özel eğitim hedeflerini, yardımcı teknolojileri, öğrencinin davranış sorunları varsa bir davranış müdahale planını içermelidir. Bu program, bir öğrencinin akademik ve sosyal ihtiyaçlarına dayalı olarak eğitim kariyerine rehberlik eden, düzenleyen ve belgeleyen yarı-sözleşmeli bir anlaşma olduğundan bir öğrencinin eğitimini yönetme, belgeleme ve iş birliğini kolaylaştırmada programın önemi göz ardı edilmemelidir (Smith ve Brownell, 1995; Washington State Department of Social and Health Services, 2010; NYC Department of Education).

BEP, özel gereksinimli bir çocuğun eğitiminde meydana gelen her şeyin taslağıdır. Eğitimcilerin eğitim faydası sağlamak için takip etmeleri gereken bir dizi kılavuz ve ebeveynlerin bu faydaların sağlanıp sağlanmadığını belirlemede izlemesi gereken yararlı bir belgedir. BEP'teki hizmetler, öğrencinin engelli olan ve engelli olmayan çocuklarla birlikte genel eğitim müfredatına göre eğitim almasına ve bu eğitime katılımının sağlanmasına, yıllık hedeflerine ulaşma yolunda uygun bir şekilde ilerlemesine ve diğer akademik olmayan faaliyetlere katılmasına yardımcı olmayı amaçlamaktadır (Kopels, Rich ve Massat, 2016).

BEP, gerekli zamanlarda düzeltilebilir ve değiştirilebilir esnek bir çalışma olarak öğrenciler, aileler, öğretmenler ve toplum açısından farklı yararlar sağlamaktadır. BEP'in yararları aşağıdaki gibi sıralanabilir (MEB, 2015):

- Çocuğun yapabileceklerinin betimlenmesi

- Çocuğa uygun eğitim hizmetleri sunulması

- Çocuğun engelinden kaynaklanan gereksinimlerinin belirlenmesi

- Çocuğun öğrenim süreciyle ilgili sorumluluk almasına yardım etmesi

- Çocuğun öğrenme sürecinin izlenmesi

- Çocuğun ilerlemelerinin kayda alınması

- Çocuğun ailesi ile BEP Geliştirme Biriminin diğer üyeleri arasındaki ilişkilere katkıda bulunması

- Çocuğun ailesi ile BEP Geliştirme Birimi üyelerinin ilişkilerine katkıda bulunması

- Çocuğun eğitimi ile ilgili kararlarda aile ile okul personeline eşit söz hakkı sağlaması

Amerika Birleşik Devletleri’nde özel eğitim sistemini düzenleyen ve 1975 yılında çıkarılan Tüm Engelli Çocuklar için Eğitim Yasası (EHA) ile özel eğitimin genel kuralları belirlenmiştir. Birkaç kez gözden geçirilerek değişime uğrayan bu yasanın adı son olarak Engelli Bireyler Eğitim Yasası (IDEA) olmuştur. IDEA, engelli çocukların okulda başarılı olmalarına yardımcı olacak özel programlar ve hizmetler sağlamak için resmi bir süreç 
sunmakta ve engelli çocukların uygun bir eğitim almalarını sağlamak amacıyla okullara yasal gereklilikler getirmektedir. IDEA kapsamında, çocuğun ihtiyaç duyduğu program ve hizmetler BEP ile belirlenmektedir. BEP, özel eğitim sürecinin ve IDEA'nın en önemli parçasıdır (Siegel, 2005; Vuran, Bozkuş-Genç ve Sani-Bozkurt, 2017).

Özel eğitim sürecinde olması gereken bir program olan BEP'ler Türkiye'de de yasal olarak desteklenmektedir. 1997 yılında kabul edilen 573 sayılı Kanun Hükmünde Kararnamenin 4. madde f bendinde özel eğitim gereksinimi olan öğrenciler için BEP geliştirilmesini ve uygulanmasını zorunlu hale getirmiştir. BEP ilerleyen süreçte 2000, 2006, 2012 ve 2018 yıllarındaki Özel Eğitim Hizmetleri Yönetmeliklerinde de düzenlenmiş ve güncellenmiştir. BEP, 07.07.2018 tarihli Özel Eğitim Hizmetleri Yönetmeliğinde "Özel eğitim ihtiyacı olan bireylerin takip ettikleri program esas alınarak gelişim özellikleri, eğitim ihtiyaçları ve performansları doğrultusunda hedeflenen amaçlara ulaşmaya yönelik hazırlanan ve bu bireylere verilecek destek eğitim hizmetlerini de içeren özel eğitim programı" olarak tanımlanmıştır (Öztürk ve Eratay, 2010; Vuran, Bozkuş-Genç ve Sani-Bozkurt, 2017; ÖEHY, 2018, Md. 4/g; Çıkılı vd., 2020).

Özel eğitime ihtiyacı olan öğrencilerin eğitimlerine devam ettikleri okul veya kurumda BEP'lerin hazırlanması için BEP Geliştirme Birimi oluşturulmaktadır. Okul/kurum müdürünün veya görevlendirilen müdür yardımcısının başkanlık ettiği BEP geliştirme biriminin üyeleri; rehber öğretmen, öğrencinin sınıf öğretmeni, öğrencinin dersini okutan ilgili alan öğretmenleri, öğrencinin velisi ve öğrencidir. Birimin çalışma usul ve esasları okul yönetimince belirlenmektedir. BEP ekibi, çocuğun bir engeli olup olmadığını, özel eğitim hizmetlerine ihtiyaç duyup duymadığını ve özel eğitime ihtiyaç varsa hangi hizmetlerin uygun olduğunu belirlemek için bilgi paylaşan ve birlikte çalışan bir grup üyedir (ÖEHY, 2018, Md. 47; NYC Department of Education).

\subsection{Okul sosyal hizmeti}

Sosyal hizmet mesleğinin bir uzmanlık dalı olarak geliştirilen okul sosyal hizmeti, yüz yıldan fazla bir süredir "çevresi içinde birey" anlayışıyla öğrencilerin akademik başarıları ile sosyal, duygusal ve davranışsal yeterliliklerini artırmalarına yardımcı olmakta, okulların, ailelerin ve toplumun çabalarını koordine etmeye odaklanmakta ve okul, aile ve toplum arasında bağlantılar sağlamaktadır (SSWAA, 2021; NASW, 2012). Aynı zamanda güvenli ve sağlıklı bir okul ortamında tüm öğrencilerin kendilerini geliştirmelerine, eğitim sürecindeki potansiyellerini en üst düzeye çıkarmalarına ve akademik ve sosyal olarak başarılı olmalarına yardımcı olmak için gerekli fırsatları, kaynakları ve desteği sağlamayı amaçlarken bunların sağlanmasında da kritik bir rol oynamaktadır (Openshaw, 2008).

Bir eğitim ortamında öğrencilerin çeşitli ihtiyaçlarının karşılanmasında önemli bir yere sahip olan okul sosyal hizmet uzmanları, öğrenciye göre değişebilen çeşitli roller üstlenir. Hizmet sundukları öğrencilerin yaşamlarının ve sosyal, duygusal, davranışsal ve akademik durumlarının iyileştirilmesini, öğrenme sürecine engel olabilecek durumların ortadan kaldırılmasını ve öğrenci refahının arttırılmasını amaçlar. Bu amaç doğrultusunda yapacağı müdahaleleri planlamak için ekolojik yaklaşımı kullanarak öğrenci, aile ve sistemler (sınıf, okul, mahalle ve ilçe gibi) düzeylerinde değerlendirmeler yapar (NASW, 2010; NASW, 2012). Kişilerarası ilişkilerin geliştirilmesi, kriz durumlarıyla başa çıkılması, öz saygı, öz denetim ve yaşa uygun sosyal beceriler geliştirilmesi ve problem çözme ile karar verme becerilerin öğrenilmesi gibi konularda öğrencilere yardımcı olurlar (ICISD, 2015). Okul sosyal hizmet uzmanları öğrencilerin ihtiyaçlarının değerlendirilmesi ve bu ihtiyaçların karşılanması konusunda çözüm yolları geliştirmesinde öğretmenler ile diğer uzmanlarla işbirliği içerisinde olup aynı zamanda okullarda oluşturulan krize müdahale ekibi gibi multidisipliner ekiplerin de üyesidir (Dupper, 2003).

Okullarda öğrencilerden beklenilenler ile öğrencinin okul ve aile hayatının yanı sıra ihtiyaçlarının karşılanması konusunda yaşanan sorunların öğrenci hayatına etkisi arasında sıklıkla farklılıklar doğabilmektedir. Eğer bu farkl11ıklar giderilemezse hem öğrenciler hem de eğitim programları ve politikaları başarısız olur. Bu noktada ailelerin, okulların ve toplulukların birbiriyle çatıştı̆̆ı, eğitimsel farklılıkların yaşandığı hatta eğitimin aksadığı yerlerde okul sosyal hizmet uzmanlarının görev alması oldukça değerlidir (Constable, 2009). Ancak ülkemizde okul sosyal hizmeti proje aşamasında kalıp yaygın olarak uygulanmamaktadır ve bu sebeple okul sosyal hizmet uzmanları yurtdışında olanın aksine özel gereksinimli öğrenciler için hazırlanan BEP uygulayıcı multidisipliner ekibinin daimi bir üyesi olamamaktadır. Yapılan literatür incelemesinde de BEP'e yönelik öğretmen görüşlerini ele alan çalışmaların (Avcıoğlu, 2011; Burunsuz ve İnce, 2020; Sevim, Kayman ve Kaya, 2021) var olduğu ancak bu çalışmalarda okul sosyal hizmetine ve okul sosyal hizmet uzmanlarına değinilmediği görülmüştür.

\section{Yöntem}

Bu araştırma T.C. Karabük Üniversitesi Sosyal ve Beşeri Bilimler Etik Kurulunun 09.04.2021 tarih ve 2021/04-08 kararı ile etik açından uygun bulunmuştur. 
Bu çalışma, öğretmenlerin BEP ile ilgili görüşlerinin ve okul sosyal hizmet uzmanlarının bu programda nasıl etkili olabileceği hakkındaki düşüncelerinin değerlendirilmesi amacı ile oluşturulan nitel bir araştırmadır. Nitel araştırma, insanların deneyimleri hakkında bilgi edinilmesini sağlayan (Silverman, 2021) ve gözlem, görüşme ve içerik analizi yoluyla veri toplamayı içeren araştırma türüdür (Patton, 2005).

\subsection{Araştırmanın amacı ve önemi}

Bu çalışmanın amacı, BEP'e, okul sosyal hizmetine ve okul sosyal hizmet uzmanlarının bu programda yer alması ile üstlenebileceği rollere yönelik öğretmen görüşlerine yer vermektir. Bu çalışmada okul sosyal hizmet uzmanlarının BEP'te yer aldığında sağlayabileceği katkılara değinilecek olması araştırmanın önemini ortaya koymaktadır.

\section{2. Çalışma grubu}

Bu çalışmada, örnekleme yöntemi olarak amaçlı örnekleme yöntemlerinden kartopu örnekleme yöntemi kullanılmıştır. Kartopu örnekleme yöntemi araştırmacının çok sayıda katılımcı bulması için avantajlı bir yöntemdir. $\mathrm{Bu}$ yöntemde araştırmacı ulaştığı katılımcılardan konu hakkında bilgi sahibi olabilecek başka katılımcılar önermesini ister ve veri toplama süreci bir kartopu gibi büyüyerek ilerler (Creswell, 2012; Yıldırım ve Şimşek, 2013). Bu bağlamda bu çalışmanın örneklemini Karabük ilinde yaşayan ve mesleki kariyerinde en az bir kez BEP dâhilinde görev almış çeşitli zümrelerden 11 öğretmen oluşturmaktadır. Katılımcıların verdiği yanıtların birbirlerini tekrarladığı anlaşıldığında görüşmeler sonlandırılmıştır. Araştırmanın gizliliğinin sağlanması amacıyla katılımcı$\operatorname{lar}$ Ö1, Ö2, Ö3... Ö11 şeklinde kodlanmıştır.

Tablo 1'de araştırma kapsamında görüşme yapılan katılımcıların cinsiyet, öğrenim durumu, branş, deneyim süresi, BEP hakkında üniversitede eğitim alma durumları ve hizmet içi eğitim alma durumları ile ilgili bilgiler yer almaktadır.

Tablo 1. Katılımcıların özellikleri

\begin{tabular}{|c|c|c|c|c|c|c|}
\hline Katılımcilar & Cinsiyet & $\begin{array}{l}\text { Öğrenim du- } \\
\text { rumu }\end{array}$ & Branş & $\begin{array}{l}\text { Deneyim } \\
\text { Süresi }\end{array}$ & $\begin{array}{l}\text { BEP hakkında üni- } \\
\text { versitede eğitim alma } \\
\text { durumu } \\
\end{array}$ & $\begin{array}{l}\text { Hizmet içi } \\
\text { eğitim alma } \\
\text { durumu } \\
\end{array}$ \\
\hline Ö1 & Erkek & Yüksek Lisans & $\begin{array}{c}\text { Edebiyat Öğret- } \\
\text { meni }\end{array}$ & $8 \mathrm{y} 11$ & Evet & Hayır \\
\hline Ö2 & Erkek & Lisans & Sınıf Öğretmeni & $25 \mathrm{y} 1 \mathrm{l}$ & Hayır & Evet \\
\hline Ö3 & Erkek & Lisans & Sınıf Öğretmeni & $30 \mathrm{y} 1 \mathrm{l}$ & Hayır & Evet \\
\hline Ö4 & Erkek & Yüksek Lisans & Sınıf Öğretmeni & $30 \mathrm{y} 1 \mathrm{l}$ & Hayır & Evet \\
\hline Ö5 & Erkek & Lisans & $\begin{array}{c}\text { Rehberlik Öğret- } \\
\text { meni }\end{array}$ & $20 \mathrm{y} 11$ & Evet & Evet \\
\hline Ö6 & Kadın & Lisans & $\begin{array}{l}\text { Özel Eğitim Öğ- } \\
\text { retmeni }\end{array}$ & $30 \mathrm{y} 1 \mathrm{l}$ & Hayır & Evet \\
\hline Ö7 & Kadın & Lisans & $\begin{array}{c}\text { Özel Eğitim Öğ- } \\
\text { retmeni }\end{array}$ & $3 \mathrm{y} 11$ & Evet & Evet \\
\hline Ö8 & Erkek & Lisans & $\begin{array}{c}\text { Özel Eğitim Öğ- } \\
\text { retmeni }\end{array}$ & $20 \mathrm{y} 11$ & Hayır & Evet \\
\hline Ö9 & Kadın & Lisans & Türkçe Öğretmeni & 23 y1l & Hayır & Evet \\
\hline Ö10 & Erkek & Lisans & $\begin{array}{c}\text { Özel Eğitim Öğ- } \\
\text { retmeni }\end{array}$ & $3 \mathrm{y} 1 \mathrm{l}$ & Evet & Evet \\
\hline Ö11 & Erkek & Lisans & Sınıf Öğretmeni & 22 y1l & Hayır & Evet \\
\hline
\end{tabular}

Tablo 1'e göre katılımcıların 8'i erkek ve 3'ü kadındır. Öğrenim durumu açısından 9 katılımcı lisans mezunu iken 2 katılımcı yüksek lisans mezunudur. Katılımcıların deneyim süreleri 3-30 yıl aralığındadır. BEP hakkında üniversitede eğitim alan katılımcıların sayısı 4 iken eğitim almayan katılımcı sayısı 7'dir. Katılımcılardan biri hariç hepsinin hizmet içi eğitim aldığı görülmektedir.

\subsection{Veri toplama aracının geliştirilmesi}

$\mathrm{Bu}$ çalışmada veri toplama aracı olarak yarı yapılandırılmış görüşme formu kullanılmıştır. Kullanılan yarıyapılandırılmış görüşme formunda ilgili literatürden yararlanılarak oluşturulan 6 kişisel bilgi sorusu ve 5 açık uçlu soru yer almaktadır. Bu soruların yanı sıra görüşme esnasında katılımcılar tarafından verilen cevaplara ve görüşmenin gidişatına göre gerekli görülen ek sorular da sorulmuştur. Görüşme formunda şu açık uçlu sorular yer almaktadir: 
1. Sizce BEP nedir? BEP hakkında görüşleriniz nelerdir?

2. Sizce BEP'in öğrenciler için avantajları ve dezavantajları nelerdir?

3. BEP'te hangi zorluklarla karşılaştınız? Uygulama esnasında zorlandığınız öğrenci grubu var mıdır, varsa bu öğrenci grupları hangileridir?

4. BEP'in uygulanmasını kolaylaştıran ve zorlaştıran öğrenci çevresi ve okulla ilgili etmenler sizce nelerdir?

5. Sosyal hizmet mesleği hakkında ne düşünüyorsunuz? Okul sosyal hizmeti uygulamaları hakkında bilgileriniz ve görüşleriniz nelerdir? Sizce sosyal hizmet uzmanları okullarda BEP Geliştirme birimindeki uygulamalara ne gibi katkılar sağlayabilir?

\subsection{Verilerin toplanmast ve analizi}

Görüşmeler gerçekleştirilmeden önce gerekli etik kurul izni Karabük Üniversitesi Sosyal ve Beşeri Bilimler Araştırmaları Etik Kurulunun 09.04.2021 tarihli 2021/04 numaralı toplantıda 08 sayılı karar numarası ile alınmıştır. Etik kurul izni alındıktan sonra görüşmeler 13.04.2021- 20.04.2021 tarihleri arasında, yaşanan pandemi sebebiyle okul dışı ortamlarda yüz yüze görüşme ve telefon aracilığıyla gerçekleştirilmiştir. Görüşmenin öncesinde katılımcılara meslek hayatları boyunca en az bir kez BEP ekibinde yer alıp almadıkları sorulmuştur. Bu ekipte yer aldığını ifade eden öğretmenlere araştırmanın amacı ve araştırmada kullanılacak kişisel özellikler ile yanıtların gizliliği konusunda bilgi verilmiş olup araştırmaya katılma konusunda gönüllü olup olmadıkları sorulmuş ve onayları alınmıştır. Görüşmeler ortalama 12 dakika sürmüştür ve görüşmeler, katılımcıların bilgisi ve onayı ile ses kaydı altına alınmıştır. Bu ses kayıtları daha sonra dinlenerek bilgisayar ortamında yazılı metin haline getirilmiştir. Verilerin analizinde betimsel ve tematik analiz yöntemi kullanılmıştır. Verilen cevaplardaki sıkça dile getirilen hususlar dikkate alınarak belirli temalar oluşturulmuş ve bazı çarpıcı görüşlere doğrudan alıntı yoluyla yer verilmiş̧ir.

\section{Bulgular ve yorumlar}

Bu bölümde öğretmenlerin BEP'i tanımlama becerisi ve BEP hakkındaki görüşleri; BEP'in öğrenciler için avantajları ve dezavatajları; BEP uygulama aşamasında yaşanan zorluklar; BEP'in uygulanmasını kolaylaştıran ve zorlaştıran etmenler; sosyal hizmet ve okul sosyal hizmeti alanına ilişkin bilgi durumu ile okul sosyal hizmeti uzmanlarını BEP uygulamalarına sağlayabileceği katkılara yönelik bulgulara ve yorumalara yer verilmektedir.

\section{1. Öğretmenlerin BEP'i tanımlama becerisi ve BEP hakkında görüşleri}

Katılımcılardan BEP'i tanımlamaları istenmiştir. Katılımcıların BEP tanımlarındaki ortak noktalar BEP'in özel gereksinimli öğrencilere uygulanması, öğrenciye özel olması, öğrencinin bilgi ve beceri seviyesiyle birlikte kapasitesine göre hazırlanması, öğrencinin ihtiyaçlarının karşılanması, uzun ve kısa dönemli hedefleri olması şeklindedir. Can'ın (2015, s. 33) yaptığı araştırmada da öğretmenlerin BEP tanımlarının benzer şekilde "performansına ve ihtiyaca göre, ihtiyaçlara göre, performansa göre, bireysel ihtiyaçlara göre, eğitsel ihtiyaçlara göre yapılan tanımlar" gibi kategorilerde toplandığı görülmüş̧ür. BEP öğretmenlerden birisi tarafından (Ö10) "BEP öğrenciye bir yılda kazandırlmasl gereken bilgi ve becerilerin planlandı̆̆ programdır. Özel eğitimde öneminin fazla olduğu ve hazırlanan plana uyulduğu takdirde verim sağlayan aile öğretmen ögrencinin iş birliği içerisinde uygulandı̆̆ plandır." şeklinde tanımlanırken bir başka öğretmen tarafından (Ö3) "Uzak ve yakın amaçları olan, hedef ve kazanımların belirlendiği öğrenci ile ilgili birebir çalışmadır." diye tanımlanmıştır.

Katılımcıların BEP'in tanımını yapabildikleri ve BEP hakkında bilgi sahibi oldukları görülmektedir. Literatür incelendiğinde Yılmaz ve Batu (2016, s. 261) tarafindan gerçekleştirilen araştırmanın bulguları ile bu araştırmanın bulgularının benzer olduğu görülmüsşür. Bu araştırmanın bulgularından farklı olarak BEP konusunda yetersiz bilgi düzeyini ortaya koyan araştırmalara da (Öztürk ve Eratay, 2010; Kuyumcu, 2011; Bedur, Bilgiç ve Taşlıdere, 2015; Akkoyunoğlu, 2019) rastlanmaktadır.

Katılımcılara BEP hakkındaki görüşleri sorulmuştur. Katılımcı görüşlerinde BEP'in öğrenciye özel olması ve öğrencinin kişisel, sosyal, kültürel, ekonomik özelliklerine, zeka düzeyine, ihtiyaçlarına ve kapasitesine göre hazırlanmış olması gerektiği vurgulanmıştır.-Bu konuda (Ö8) "Tamamen bireyin özelliklerine göre hazırlanmalıdır. Aynı sinıfta olan ögrrenciler bile farklı BEP'e ihtiyaç duyabilirler." şeklinde görüş bildirirken (Ö6) ise "İhtiyacı olan ögrenciye uygulanmalı BEP'i uygulayacak zaman, ortam verilmelidir." demiştir. Katılımcılardan bazıları (Ö2, Ö7 ve Ö9) BEP'in gerekliliğine vurgu yapmışlardır. Literatür incelendiğinde yapılan araştırmalarda da (Öz- 
türk ve Eratay, 2010; İlik, 2019; Kesici, 2019; Evyapan, 2020) katılımcıların BEP'in gerekliliğine değindiği görülmüştür.

BEP'in gerekliliği konusunda bir öğretmen "Öğrenci normal seviyeden düşük ya da normal seviyenin üstünde bir ögrenciyse farkl eğitim-öğretim programlarına ihtiyaç duymaktadır. Bu yüzden gerekli bir programdır. ”(Ö2) derken bir başka öğretmen "Her ögrenci kendine özgü ve biriciktir. Her birinin ögrenme şekli ve algl seviyesi farklllk gösterir. Bunun yanina bir de özel gereksinim eklendiğinde BEP mutlaka olması gereken bir şeydir." (Ö7) demiştir. Öğretmenlerden birisi de "BEP amacına uygun şekilde yapıldı̆̆ında gerekli bir programdır." (Ö9) şeklinde görüş bildirmiştir.

\subsection{BEP'in ögrrenciler için avantajları ve dezavantajları}

Katılımcıların görüşleri BEP'in avantajları açısından, özel gereksinimli çocuğa göre hazırlanması, öğrencinin özgüveninin artması ve öğrencinin okula uyumunun sağlanması konularında ortaklık göstermektedir. Katılımcılar BEP'in öğrenciler için farklı açılardan avantajlı olduğunu belirtmektedir. Literatür incelendiğinde yapılan araştırmalarda da (Kuru Habiboğlu, 2018; Evyapan, 2020; Sevim, Kayman ve Kaya, 2021) bu bulgular ile paralel olarak BEP'in öğrenciler için yararlı olduğunun vurgulandığı görülmektedir.

Bu konuda (Ö4) “Avantajı öğrenci kendini toplumdan farklı görmüyor. Aynı kişilerle çallş̧tı̆̆ iç̧in, çocuklar akranlarıyla olduğu için kendini dışlanmış, soyutlanmış hissetmiyor." derken (Ö3) ise "Avantajı şu şekilde yani çocukla birebir ilgilendiğiniz için daha kalıcı ögrenme sağlanabiliyor. Öğrenciye davranışlarında değiş̧iklik kazandirabiliyorsunuz. " şeklinde görüş bildirmiş̧tir.

Katılımcılar BEP' in dezavantajlarını öğrenciye önyargılı davranılması, öğrencinin programa sürekli devam etmemesi/ devamsızlık, öğrencinin kendini diğer öğrencilerden soyutlaması ve diğer öğrencilerin de BEP uygulanan öğrenciyi dışlaması şeklinde belirtmişlerdir. Katılımcılardan ikisi (Ö9 ve Ö10) BEP' in dezavantajı yoktur diyerek görüş bildirmişlerdir.

BEP'in dezavantajları konusunda (Ö1) "BEP uygulanan öğrencilerin devamsılılk yapmaları durumunda BEP hedeflenen amaç ve kazanımlara tam ulaşamiyor. Planda esneklik yapmak gerekiyor." ve (Ö2) "Bu tür öğrencilere bazen BEP uygulandı̆̆ için önyargll davranılmakta ve yeterince ilgi gösterilemeyebilmektedir. Arkadaşları tarafindan dışlanabiliyorlar." derken (Ö4) "Sinıfta öğretmen eğer dengeyi kuramazsa ve çocuğun bireysel yaptsına göre davranmazsa çocuk kendini düşük seviyede hisseder. Diğer çocuklar da onu dışlama yoluna gidebilir." şeklinde görüş bildirmiştir.

\subsection{BEP'i uygulama aşamasında yaşanan zorluklar}

Katılımcıların büyük çoğunluğu BEP uygulanmasında zorluklar yaşadıklarını dile getirmişlerdir. BEP uygularken yaşanılan bu zorluklar öğrenciler ile ilgili zorluklar, veliler ile ilgili zorluklar ve okulla ilgili zorluklar şeklinde üç başlık altında toplanabilir. Öğrenci ile ilgili zorluklarda öğrencinin engel türü, kişisel özellikleri ve iletişim becerileri, en sık dile getirilen zorluklardır. Engel türü açısından ise katılımcıların büyük kısmı, ağır bedensel engelli, zihinsel engelli, konuşma engelli, disleksi ve otizmli öğrencilerde BEP uygulaması esnasında zorluk yaşadıklarını belirtmişlerdir. Öğrenci ile ilgili yaşanan zorluklar konusunda öne çıkan yanıtlar şu şekildedir:

"Yani çocuğa verdiğin eğitimi sürekli tekrar ediyormuşsun gibi geliyor. Çocuk kavrayamıyor, kavrasa bile bir gün sonra unutup gelebiliyor. Yani akıntıya karşı kürek çekmek gibi bir şey. Günlerce aynı şeyi veriyorsun ama bir anda sıfirlayıp geliyor sanki hiç görmemiş gibi hiç bu konu ile muhatap olmamış gibi çocuk sifirlayıp geliyor. Bu da bende acayip moral bozukluğu yapiyor." (Ö3)

"iletişim becerileri eksik öğrencilerde zorlandım. Geri bildirim alabildiğim öğrencilerle işlediğim dersler daha güzel ve verimli geçti bence. İletişime kapalı ögrencilerde geri bildirim alamadiğımızda konuların ögrenilme düzeyini belirlemek daha zor." (Ö1)

"Konuşabildiği halde konuşmayı reddeden bir öğrencimde hiç verim elde edemedim." (Ö9)

Velilerden kaynaklı zorluklarda en çok dile getirilen zorluklar velilerin çocuklarının engel durumlarını kabullenememesi, uygulama sürecinde ailelerin çocuklarılya ilgili yüksek beklentileri olması ve velilerle işbirliği yapma konusunda sıkıntılar yaşanması olmuştur. İlgili literatür incelendiğinde de BEP'in uygulanma sürecinde velilerle ilgili benzer zorluklar yaşandığı görülmüştür (Avcıoğlu, 2011; Taşdemir vd., 2017; Özan, 2019). Bu hususlara ek olarak (Ö4), "Aileler çocukları daha çalışkan olan çocuklarla otursun istiyorlar veya daha iyi durumda olan ço- 
cukla. Biraz problemli olan çocuktan uzak olma ihtiyacı duyuyor veya eğitim olarak anlamakta zorluk çeken çocuklarda damgalama durumu var bizde... Mesela bir öğrencim vardı, veliler onu okulda istemediler... Birkaç kez Milli Eğitime şikâyete filan gittiler. 'Çocuk engelliler okuluna alınsın buranın çocuğu değil' dediler.” diyerek yalnızca özel gereksinimli çocukların velilerinin değil diğer çocukların velilerinin de BEP uygulama sürecini zorlaştırdığını dile getirmiş̧tir. Benzer şekilde, Yaman'ın (2017) sınıf öğretmenleriyle gerçekleştirdiği çalışmada da katılımcılar, BEP uygulanırken diğer çocuklarla ve bu çocukların velileriyle sorunlar yaşadığını belirtmiş̧lerdir.

Okulla ilgili zorluklarda ise okullarda BEP'in uygulanmasına zaman olmaması, okullarda bu programın uygulanması için gerekli materyallerin eksik olması ve sınıfların BEP'in uygulanmasına uygun ortamlar olmaması, ortaklık gösteren hususlar olmuştur. Literatür incelendiğinde bu hususların bu konuda gerçekleştirilmiş araştırmalarla benzerlik gösterdiği görülmüştür (Debbağ, 2017; Şahin ve Gürler, 2018; Sevim, Kayman ve Kaya, 2021). Bu hususların dışında (Ö7) "BEP kurulunda aile ve okul arasında ortak karar alınmast ve öğrencinin performansı alınırken kararlı verilerin (3-4 kararlı veri alınması gerek) toplanması konularında zorluklar yaşadım. İlk izlenimde BEP hazırlanması isteniyordu, bu da zorluk çıkarlyordu. Oysaki ögrenciyi yakından tanımak gerekiyor." diyerek BEP ile ilgili yaşadığı farklı zorluklara değinmiştir. BEP uygulamasında zorluk yaşamadığını belirten (Ö11), “Çocuğu iyi tanımamız gerekiyor. Öğrencinin gelişimine göre plan hazırlamak zorundayız. Genelde sıkıntı olmuyor çocukların özel durumlarını göz önüne aldığımızda ve bilmemiz gerekenleri göz ardı etmeden plan hazırlyyoruz sıknntı olmuyor genelde." diyerek zorluk yaşamama nedeni olarak BEP'in öğrenciye uygun olacak şekilde hazırlanmasını göstermiştir.

\subsection{BEP'in uygulanmasını kolaylaş̧ıran ve zorlaştıran etmenler}

Katılımcıların verdiği yanıtlara göre öğrencinin akademik ve zihinsel düzeyinin doğru tespit edilmesi, BEP'in öğrencinin ihtiyaçlarına cevap verecek nitelikte olması, ders programlarının yoğun olmaması, özel gereksinimli öğrencinin okula düzenli olarak devam etmesi ve aile ile işbirliğinin sağlanması, BEP'in uygulanmasını kolaylaştırmaktadır. Bu konuda (Ö2) "Okullarda gerekli birimlerin olması, ilçe rehberlik servislerinin olması, benzer öğrencileri olan sınıf öğretmenlerinin olmast işleri kolaylaştırıyor.", (Ö7) "Erken tant ile okul çağına gelmiş bireylerde ailenin ön koşul bilgilerinin olması, idarenin ve okuldaki diğer branşların ortak katklları BEP'in uygulanmasını kolaylaştırır." ve (Ö6) "Destek sinıflarının ve özel-alt okulların yayginlaştırılması BEP'lerin uygulanmasını kolaylaştıracaktır." diyerek görüş bildirmişlerdir.

Katılımcıların verdiği yanıtlara göre BEP'in uygulanmasını zorlaştıran etmenler arasında en çok dile getirilenler, velilerle iletişimde ve işbirliğinde sıkıntıların olması, velilerin olumsuz tutumları ve çocuklarının durumunu kabullenemeyişleri olmuştur. Literatür incelendiğinde bu bulgulara benzer sonuçlar ortaya koyan birçok araştırmaya rastlanmıştır (Tekin Ersan ve Ata, 2017; Yaman, 2017; Toprak, 2018). Bu konuda ön plana çıkan yanıtlar şu şekildedir:

"Ailede bazı sıkıntılar oluyor. Aileler kabullenmek istemiyor çocuğunun böyle bir durumu olduğunu, akranlarından geri olduğunu kabul etmiyor veli. Genelde çocuğunun kaynaştırma olmadı̆̆ın düşünüyor veya normal ögrrenciler gibi eğitim alması gerektiğini düşünüyor. Veliler ile bu tip sılkntılar oluyor." (Ö11)

"Bir kere velinin çocuğunu kabullenmesi gerekiyor. Benim çocuğum bu şekilde öğrenecek diye. Velinin bir şekilde eğitimin içinde olması gerekiyor. Sürecin ögrretmen-veli-okul iş birliği ile yürütülmesi gerekiyor. Veli boş verdiği an çocukta geri gitmeler ortaya çıklyor. Yani zor yönleri var. Ĕger veli kabul etmiyorsa çocuğu çok zor. Velinin kabul etmesi zor bir olay. Öğrencinin böyle öğreneceğini kabul edemiyor veli. Velinin de psikolojik destek alması lazım. Veli bana geliyor her geldiğinde ağllyor neden öğrenemiyor diye zamanla bu hemen olmayacak diyorum. Kesinlikle velinin işin içinde olması lazım. "(Ö3)

Velilerle ilgili etmenlerin yanı sıra öğrenci devamsızlığı, hazır BEP kullanımı, öğrenci ihtiyaçlarının dikkate alınmaması, materyal eksikliği, okul idaresinin ve öğretmenlerin BEP ve BEP birimi hakkında bilgiye sahip olmaması ve özel gereksinimli öğrencileri kabullenememesi gibi etmenler de BEP'in uygulanmasını zorlaştıran etmenler olarak dile getirilmiştir. İlgili literatür incelendiğinde bu bulguların birçok araştırmayla oldukça uyumlu olduğu görülmüştür (EARGED, 2010; Kuyumcu, 2011; Taşdemir vd., 2017). Bu konuda öne çıkan yanıtlar şu şekildedir:

"Branş öğretmenleri ve slnıf öğretmenlerinin de eğitimden geçmesi gerekiyor. Onlar kabullenemiyorlar.

Onlar şimdi tahtaya çıkıp sadece dersi yapıp gidince dersin bittiğini zannediyor. Çocuğun evdeki duruтипи, aile yapısını, hiçbir şeye o kadar fazla eğilmiyorlar... O sinıflara da kabul etmiyorlar onları. Ne yapıyor? Diyor ki bu sinıf benim. Buradan çıkıyor öbür sinıfa gidiyor ve bu sinıfi unutuyor... Okul idaresi 
de bunu kabullenecek. Ondan (özel gereksinimli öğrenciden) normal bir davranış beklemeyecek... Onlardan diğer öğrencilerden beklediğin her şeyi beklersen sıkıntı yaşarsın. Yani onu kaybedersin doğrusu. Onun için onun ayrıcalıkları olacak. Soracaksın, çözeceksin, takip edeceksin niye yapıyor...” (Ö4)

"Öncelikle kurum idare ve ögretmenlerinin BEP ve kurulu hakkında bilgiye sahip olmamasl zorlaştırmaktadır. Bunun yanında ögretmenlerin yetersiz bilgisi ve ailenin isteksizliği BEP'in genelleme ve kalıcılık aşamalarında başarısızlıklara neden oluyor. "(Ö7)

4.5. Sosyal hizmet ve okul sosyal hizmeti alanına ilişkin bilgi durumu ile okul sosyal hizmet uzmanlarının BEP uygulamalarına sağlayabileceği katkılar

Verilen yanıtlara bakıldığında katılımcıların büyük çoğunluğunun sosyal hizmet alanını bildiği görülmüştür. Katılımcılar sosyal hizmetin en çok aile, çocuk, engelli ve yaşlı alanlarını bildiklerini dile getirmişlerdir. Katılımcılardan (Ö9), "Sosyal hizmet deyince Amerikan filmlerinde çocuklarl almaya gelen bir kadın ve bir erkek aklıma geliyor. Hangi alanda tam anlamıyla ne gibi bir hizmet yaptı̆̆ tam olarak anlaşılamayan bir alan olduğunu düşünüyorum." diyerek sosyal hizmeti tam olarak bilmediğini belirtmiştir.

Katılımcılardan (Ö7) “Toplum sağlı̆̆ı ve huzuru için açılan kurumlarda çalışan, bu alanlar ile ilgili çalışmalarda ve araştırmalarda bulunan kişiler olarak biliyorum.” ,(Ö1) "Dezavantajlı kişilerin topluma kazandırılması ve toplumun gelişimi açısından önemli bir alan olduğunu düşünüyorum sosyal hizmetin. Temelindeki dezavantajlı bireylerin güçlendirilmesi ilkesi sebebiyle güçlü bireylerin güçlü bir toplum oluşturacağına inanıyorum. ”ve (Ö8) "Sosyal hizmet mesleği bugün için toplumumuzda zorunlu hale gelmiştir. Ailelere ve çocuklara ulaşmak, onların dertlerini dinlemek ve öğrenmek, çözüm üretebilmek için bu konuda formasyon almış kişilere ihtiyaç duyulacağ açıktır.” diyerek sosyal hizmet alanı hakkında sahip oldukları bilgileri dile getirmişlerdir.

Katılımcıların sosyal hizmet alanını bilmelerine rağmen okul sosyal hizmeti alanı hakkında bilgi sahibi olmadıkları görülmüştür. Örneğin (Ö11), “Okulda sosyal hizmetler var. Mesela ben çocuklarl ders dişında sosyal etkinlikler yapıyorum mesela masa tenisi ögretiyorum, satranç tiyatro gibi sosyal faaliyetler olabiliyor. Bu tip faaliyetler var okulda." yanıtı ile okulda gerçekleştirilen sosyal aktiviteleri okul sosyal hizmeti olarak değerlendirmiştir. Katılımcılar, okul sosyal hizmeti hakkında bilgi sahibi olmasalar da okul sosyal hizmetinin gerekli olduğunu dile getirmişlerdir.

Katılımcıların okul sosyal hizmetinin gerekliliği ve sosyal hizmet uzmanlarının okullarda yerine getirebilecekleri görevler konusunda (Ö4) “Aslında sosyal hizmet uzmanları evet, kesinlikle sosyal hizmet uzmanı olmalı birebir iletişim sağlanması gereken, yoksulluk, anne- baba ayrllıkları aile içi şiddet gibi şeylerin tespitinde... Bilhassa engelli çocuklarla ilgili... En azından teneffüse çıktı̆̆ zaman bile onlarla birlikte olabilecek, onlarla ayrı bir iletişim kurabilecek... Çünkü onlar tek kalıyor diğer çocuklar normal oyunlar oynadığ zaman bu çocuklar onlara uyum sağlayamıyor. O alanda bu eksikliği giderebilirler... Kesinlikle sosyal hizmet uzmanlarının olması, eğitimini almış olması gerekiyor. Ama okullarda sosyal hizmet uzmanı kesinlikle olmalı. Hiç olmasa bölgenin olmall. Mesela üç dört okulun en az bir sosyal hizmet uzmanı olmalı. Envanter tutulmalı. Öğretmenle müşterek çalışmalı." ve (Ö2) "Sosyal hizmet uzmanlarının okulda bulunması ögrencilerin anlaşılması, eksikliklerin giderilmesi ve topluma kazandırılması için faydalı olacaktır. ” şeklinde görüş bildirmiştir.

Katılımcıların okul sosyal hizmet uzmanlarının BEP'e sağlayabileceği katkılara dair görüşleri ise şu şekildedir:

“Sosyal hizmet uzmanları BEP'te alınan amaçların ögrenci için uygulanabilirliği alanında hizmet verebilir. ” (Ö6)

“Özel gereksinimli bireylere BEP hazırlamaktaki amaç bağımsız yaşam becerilerini kazandırmaktır. BEP uygulamasının mümkün olması için iyi bir araştırma şarttır. Okul-aile-toplum iş birliğinin sağlaması ve uygulanmasını sağlamada sosyal hizmet uzmanları köprü görevi tutabilir. Aileye danışmanlık hizmeti sunma ya da okuldaki eğitiminin uygulanması için gerekli koşulları sunabilir mi diye araştırma yapma konularında yardımcı olabilirler." (Ö7)

“BEP uygulanan ögrrencilerin bütünsel olarak ihtiyaçlarının giderilmesinde, ögrencinin gelişiminde ve öğrencinin ailesi ve okul arasındaki iletişimi geliştirerek sürecin daha iyi planlamasında katkı să̆layacağını düşünüyorum. Sosyal uyum ve iletişim açısından son derece etkili olacă̆ına inanıyorum.” (Ö1)

Akyüz (2018, s. 97-99) tarafindan ilköğretim öğretmenleriyle gerçekleştirilen araştırmada, öğretmenlerin sosyal hizmet mesleğine yönelik belirli düzeyde bilgi birikimine sahip olduğu ve sosyal hizmetin çocuk, aile ve toplum gibi uygulama alanlarında var olduğunu bildiği görülmüştür. Ayrıca araştırma sonuçlarına göre öğretmenler 
sosyal hizmet mesleğine olumlu bakmakta ve okullarda sosyal hizmet biriminin gerekli olduğunu düşünmektedir. Benzer şekilde Kuli ve Yıldırım'ın (2019, s. 566-569) rehber öğretmenleriyle yaptıkları çalışmada da rehber öğretmenlerinin sosyal hizmet mesleği ve sosyal hizmetin çalışma alanları hakkında bilgi sahibi olduğu ortaya konmuştur. Rehber öğretmenleri ‘çocuk ve kadın’ alanlarının sosyal hizmette en çok çalışılan alanlar olduğunu belirtmişlerdir. Yine aynı araştırmada okul sosyal hizmeti hakkında bilgi sahibi olan ve olmayan rehber öğretmenlerin oranının birbirine yakın olduğu ancak rehber öğretmenlerinin büyük bir kısmının okullarda sosyal hizmet uygulamalarının gerekli olduğunu düşündüğü görülmüsstür. Okul sosyal hizmetinin ülkemizde proje aşamasında kalıp yaygın uygulamaya geçilememiş olması ve Karabük ilinin de okul sosyal hizmeti projesinin pilot illerinden biri olmayışı sebebiyle katılımcıların okul sosyal hizmeti hakkında bilgi sahibi olmamaları ya da sahip oldukları bilgilerde eksiklik ve yanlışlık olması normal olarak görülebilir.

Oysaki okul sosyal hizmet uzmanları birçok ülkede dikkat eksikliği ve hiperaktivite bozukluğu yaşayan, öğrenme güçlüğü olan, duygusal rahatsızlıklara sahip veya otizmli öğrencilere sunulan hizmetlerde sıklıkla yer almakta ve mesleki bilgi ve becerilerini kullanarak bu öğrencilerin başarılı olmalarına yardımcı olmak için çalışmaktadır (Dupper, 2003; Openshaw, 2008). BEP özelinde bakıldığında da okul sosyal hizmet uzmanlarının bu programın oluşturulması ve uygulanmasında birçok görev üstlendiği görülmektedir. Özellikle BEP'in hazırlanması sırasında okul sosyal hizmet uzmanlarının sağlayacağı katkılar, programda yapılan öneriler üzerinde önemli bir etkiye sahiptir. Okul sosyal hizmet uzmanları BEP'in oluşturulmasına ve uygulanmasına yardımcı olmak için gözlem ve öğrencileri tanıyan kişilerle görüşme yoluyla öğrencinin eğitimine ve okula uyumuna etki eden ailevi durumları ile fiziksel ve zihinsel engelleri hakkında bilgi toplayarak bu bilgileri değerlendirir. BEP'in hedeflerine ulaşması için okul içinde ve dışında birçok hizmeti seferber eder. Okulda, evde veya yaşanan mahallede öğrencinin eğitim başarısını etkileyen zorlukları çözmek için çalışır. Öğrenciye ve ailesine engel durumuyla başa çıkmalarına yardımcı olacak hizmetlerin yanı sıra bireysel ve grupla danışmanlık, aile danışmanlığı, özel ders, sosyal beceri sınıfları ve ebeveyn sınıfları gibi hizmetler de sağlar. Bu gibi mikro düzey hizmetlerin yanı sıra engelli öğrenciler için savunuculuk ve politika geliştirme faaliyetlerinde yer alır (Constable, 1999, akt. Dupper, 2003; Openshaw, 2008; Ritter ve Ofahengaue Vakalahi, 2015; Kopels, Rich ve Massat, 2016). Sosyal hizmet uzmanları ayrıca BEP sürecinin hem yasal hem etik şekilde yürütülmesini sağlamada da önemli bir rol üstlenir (Raines ve Dibble, 2017).

Yurt dışında 1975 yılında 'Tüm Engelli Çocuklar İçin Eğitim Yasası (All Handicapped Children Act)' adıyla yürürlüğe konulan, 1990 yılında içeriği ile ismi değiştirilen ve en son 2004 y1lında güncellenen 'Engelli Bireyler Yasası (Individuals with Disabilities Education Act- IDEA)' isimli yasada, okul sosyal hizmetleri ele alınmıştır (NASW, 2012; IDEA Website, 2021a). Aynı yasanın uygulama yönetmeliğinde (IDEA Website, 2021b) okul sosyal hizmet uzmanlarının sunacağı hizmetler şu şekilde ifade edilmiştir:

- Engelli bir çocuğun sosyal ve gelişimsel öyküsünün hazırlanması;

- Çocuk ve aile ile grup ve bireysel danışmanlık;

- Bir çocuğun içinde yaşadığı ev, okul ve toplumda çocuğun okula uyumunu etkileyen sorunlar üzerinde ebeveynler ve diğer kişiler ile ortak bir çalışma yürütme;

- Çocuğun eğitim programında olabildiğince etkili bir şekilde öğrenmesini sağlamak için okul ve toplum kaynaklarını seferber etmek ve,

- Olumlu davranışsal müdahale stratejileri geliştirilmesine yardımcı olmak.

Yurt dışında BEP için temel olan yasa ile bu yasanın uygulama yönetmeliğinde okul sosyal hizmeti ele alınmış ve okul sosyal hizmet uzmanlarının rollerinin açıkça belirtilmiş olsa da ülkemizdeki en güncel Özel Eğitim Hizmetleri Yönetmeliğinde (ÖEHY, 2018) okul sosyal hizmet uzmanlarına tanımlanmış bir görev henüz bulunmamaktadır. Dolayısıyla okul sosyal hizmet uzmanları her BEP içerisinde yer alamamaktadır. Görüşme, doğrudan gözlem, standart araçlar, anketler ve odak grupları gibi yöntemler yoluyla sistematik değerlendirme, veri toplama ve yorumlama becerilerine sahip ve öğrencinin öğrenmesinin önündeki engellerin kaldırılmasında gerçekleştirilecek müdahaleler için öğrenciler hakkında geçerli ve güvenilir değerlendirmeler yapabilecek olan okul sosyal hizmet uzmanları (NASW, 2012), BEP'in mutlaka bir üyesi olmalıdır.

\section{Sonuç, tartışma ve öneriler}

Bireyselleştirilmiş Eğitim Programı, özel gereksinimleri nedeniyle akranlarından farklı eğitim ihtiyaçları olan öğrencilerin eğitiminde kullanılan ve onların bireysel özelliklerine göre hazırlanan bir özel eğitim programıdır. Özel gereksinimli öğrencilerin ihtiyaçlarına göre hazırlanan BEP'lerin uygulanması için okul/kurumlarda BEP 
Geliştirme Birimleri oluşturulmaktadır. Bu birime okul/kurum müdürü veya müdür tarafindan görevlendirilen müdür yardımcısı başkanlık etmektedir. Birimin üyeleri ise rehber öğretmen, öğrencinin sınıf öğretmeni, öğrencinin dersini okutan ilgili alan öğretmenleri, öğrencinin velisi ve öğrencidir (ÖEHY, 2018, Md. 47). Çevresi içinde birey anlayışını odağına alan okul sosyal hizmet uzmanları özel gereksinimli öğrencilerin farklı ihtiyaçlarının tespit edilmesi, okul-aile-öğrenci arasında bağlantı kurulması, BEP uygulamasına etkin veli katılımının sağlanması ve bunun önündeki engellerin kaldırılmasında önemli görevler üstlenmektedir. Bu bakımdan okul sosyal hizmet uzmanlarının BEP Geliştirme Biriminde yer almasının pek çok açıdan yararları olacaktır.

$\mathrm{Bu}$ çalışma, öğretmenlerin BEP ile ilgili görüşlerinin ve okul sosyal hizmet uzmanlarının bu programda nasıl etkili olabileceği hakkındaki düşüncelerinin değerlendirilmesi amacı ile oluşturulan nitel bir araştırmadır. Çalışma kapsamında Karabük ilinde yaşayan ve mesleki kariyerinde en az bir kez BEP dâhilinde görev almış çeşitli zümrelerden 11 öğretmen ile görüşülmüştür. Çalışmada öğretmenlerin BEP, sosyal hizmet ve okul sosyal hizmet mesleği ve okul sosyal hizmet uzmanlarının BEP’te yer alabilme durumu ile BEP'e sağlayabileceği katkılara ilişkin görüşlerine yer verilmiştir.

Katılımcıların BEP tanımı yapabildikleri ve BEP hakkında bilgi sahibi oldukları görülmüştür. BEP'in özel gereksinimli öğrencilerin eğitimi için kullanıldığını ve etkin kullanıldığında gerekli ve yararlı bir program olduğunu belirtmişlerdir. Katılımcıların BEP tanımlama becerilerinde ve BEP hakkında bilgi sahibi olmalarında katılımcıların tümünün meslek hayatlarında en az bir kez BEP uygulamış olması ve katılımcılardan çoğunun hizmet içi eğitim almış olmasının etkili olduğu düşünülmektedir. Literatürde bu araştırmadan farklı olarak BEP hakkında bilgi düzeyinin düşük olduğunu ortaya koyan araştırmalar da (Öztürk ve Eratay, 2010; Kuyumcu, 2011; Bedur, Bilgiç ve Taşlıdere, 2015; Akkoyunoğlu, 2019) mevcuttur.

Katılımcılar farklı açılardan BEP'in avantajlarını ve dezavantajlarını belirtmişlerdir. Katılımcılara göre BEP'in öğrencinin eğitim olanaklarından yararlanmasını sağlaması, okula uyumu olumlu yönde etkilemesi ve öğrencinin gelişiminin ayrıntılı şekilde takip edilmesi gibi pek çok avantajı bulunmaktadır. Bununla birlikte bir katılımcıya göre etkili veli işbirliği de BEP sürecinde avantaj sağlamaktadır. Katılımcılara göre BEP uygulanan öğrenciye önyargılı davranılması, öğrencinin devamsızlık yapması ve öğrencinin dışlanması ise BEP'in dezavantajlarındandır. BEP'in dezavantajlarının giderilmesi hususunda diğer öğrencilerin ve gerekirse diğer velilerin BEP uygulaması konusunda bilgilendirilmesinin etkili olacağı düşünülmektedir. Katılımcılar, BEP'i uygularken ögrenciler ile ilgili (öğrencinin engel türü, kişisel özellikleri ve iletişim becerileri), veliler ile ilgili (ailelerin çocuklarının durumlarını kabullenememesi, çocuklarına dair yüksek beklentileri ve işbirliği yapmama) ve okulla ilgili (zamanla ilgili sorunlar, materyal eksikliği, sınıf ortamlarının elverişsizliği) zorluklar yaşadıklarını belirtmişlerdir. Katılımc1ların ifade ettikleri hususların literatürle oldukça uyumlu olduğu görülmüştür (Avcığlu, 2011; Debbağ, 2017; Taşdemir vd., 2017; Yaman, 2017; Şahin ve Gürler, 2018; Özan, 2019; Sevim, Kayman ve Kaya, 2021).

Katılımcılar, BEP'in uygulanmasını kolaylaştıran etmenler olarak öğrencinin akademik ve zihinsel düzeyinin doğru tespit edilmesi, BEP'in öğrencinin ihtiyaçlarına cevap verecek nitelikte olması, ders programlarının yoğun olmaması, özel gereksinimli öğrencinin okula düzenli olarak devam etmesi ve aile ile işbirliğinin sağlanmasını öne sürmüşlerdir. BEP'in uygulanmasını zorlaştıran etmenlerde en sık dile getirilen, velilerle ilgili sorunlar olmuştur. Bu sorunlar velilerle iletişimde ve işbirliğinde sıkıntıların olması, velilerin olumsuz tutumları ve çocuklarının durumunu kabullenemeyişleridir. Çuhadar (2006), yaptığı araştırmada BEP hazırlık sürecinde öğrencinin ailesinden öğrencinin gereksinimiyle ilgili tam bilgi alınamadığı sonucuna ulaşmıştır. Bir başka araştırmada özel gereksinimli öğrenci velilerinin çocuklarına verilecek eğitimi sadece merak ettiklerini, çocuğunun engelinin türünü, BEP'in nasıl hazırlandığı ve yürütüldüğünü veya çocuğu ile kendisinin hangi haklara sahip olduğunu öğrenme konusunda istekli olmadıkları görülmüştür (EARGED, 2010).

Oysaki veli katılımı, BEP'in gelişiminin anahtarıdır (Kopels, Rich ve Massat, 2016). Nihayetinde özel gereksinimli çocuğu en iyi tanıyan kişiler, çocuğun velileridir. Veliler çocuklarının güçlü yönleri, ihtiyaçları, öğrenme yolları, ilgi duyduğu alanları ve bunlar gibi sadece onların bilebileceği diğer konular hakkında bilgi ve fikirlerini paylaşarak çocuklarının eğitiminin geliş̧tirilmesine katkı sağlayabilirler. Ek olarak, çocuklarının okulda öğrendiği becerileri evde kullanıp kullanmadığını rapor edebilir ve bu becerileri desteklemek için okul içinde veya dışında etkinlikler düzenleyebilirler (NICHCY, 2000; Santos vd., 2012). Nitekim Özel Eğitim Hizmetleri Yönetmeliği'nde (ÖEHY, 2018, Md. 47) de okullarda BEP'in hazırlanması amacıyla oluşturulan 'BEP Geliştirme Birimi' üyelerinin arasında velilere de yer verilmektedir.

Bu noktada okul sosyal hizmet uzmanlarının varlığı veli katılımının sağlanması konusunda oldukça önemlidir. Okul sosyal hizmet uzmanları BEP ekibinde nasıl etkin olarak yer alabileceklerini anlamaları için özel gereksinimli öğrencilerin ailelerine yardımcı olur (Openshaw, 2008). Duyumsadıkları stres ve endişenin azaltılması için 
velileri BEP sürecinde ve gerçekleştirilecek bireysel toplantılarda karşılaşabilecekleri durumlar ile bu süreç boyunca sahip oldukları haklar konusunda eğitir. Ailelerin katılımını sağlamak için toplantıları velilerin uygun oldukları zamanlarda planlar ve katılımın önündeki ulaşım engellerini kaldırmak için çalışır. Okul sosyal hizmet uzmanları aynı zamanda aileleri toplumsal ek kaynaklara ulaşımını sağlamaya yardım etmede önemli bir konuma sahiptir (Powers, Swick ve Cherry, 2017).

Velilerle ilgili nedenlerin yanı sıra öğrenci devamsızlığı, hazır BEP kullanımı, öğrenci ihtiyaçlarının dikkate alınmaması, materyal eksikliği, okul idaresinin ve öğretmenlerin BEP ve BEP birimi hakkında bilgiye sahip olmaması ve özel gereksinimli ögrencileri kabullenememesi gibi etmenler de katılımcılara göre BEP'in uygulanmasını zorlaştırmaktadır. Literatür incelendiğinde de benzer bulgulara rastlanılmıştır (EARGED, 2010; Kuyumcu, 2011; Taşdemir vd., 2017).

Rehberlik öğretmenleri ile gerçekleştirilen bir araştırmada öğretmenlerin BEP hazırlama konusunda yetersiz olduğu, öğrencinin özelliklerini, gereksinimlerini ve öğrenme düzeyini dikkate almadığı hatta birçok öğretmenin hazır BEP'lerden yararlandığı ortaya konmuştur (Demirbilek ve Levent, 2020). Camadan (2012), yaptığı çalışmada hizmet içi eğitim alan öğretmenlerin almayan öğretmenlere kıyasla BEP hazırlama konusunda öz-yeterliliklerinin yüksek olduğu sonucuna ulaşmış ve öğretmenlik alanında üniversite müfredatlarına BEP ile ilgili ayrı bir ders eklenmesi ile hizmet içi eğitimlerde beceri kazandıracak uygulamalı çalışmalara yer verilmesi önerisinde bulunmuştur.

Katılımcıların büyük çoğunluğunun sosyal hizmet alanın bildiği görülmüştür. Katılımcılar sosyal hizmetin en çok aile, çocuk, engelli ve yaşlı alanlarını bilmektedir. Katılımcıların sosyal hizmet alanını bilmelerine rağmen okul sosyal hizmeti alanında bilgi sahibi olmadıkları anlaşılmışıır. Buna rağmen katılımcılar okullarda sosyal hizmet uzmanlarının yer alması gerektiği konusunda hemfikirdir. Ayrıca katılımcılar okul sosyal hizmet uzmanlarının BEP'e BEP'in uygulanabilirliğinin sağlanması, okul ve aile arasında iletişim ve işbirliğinin geliştirilmesi, özel gereksinimli öğrencinin ihtiyaçlarının giderilmesi ve sosyal uyumunun sağlanması ile ailelere danışmanlık hizmeti sunma gibi konularda katkı sağlayabileceğini düşünmektedir. Bu bulgular, Akyüz (2018) ile Kuli ve Yıldırım'ın (2019) çalışmalarıyla oldukça benzerdir.

Güleç-Aslan ve diğerlerinin (2014) özel eğitim alanında çalışan öğretmenlerle gerçekleştirdiği çalışmasında katılımcılardan biri, BEP hazırlama sürecinde özel gereksinimli çocuğun ailesi ve yaşadığı yer gibi okul dışındaki yaşamını gözlemlemeye ihtiyaç duyduğunu belirtmiştir. Bu noktada özel gereksinimli öğrencinin okul dışındaki yaşamının gözlemlenmesinde okul sosyal hizmet uzmanları önemli roller üstlenebilir. Örneğin ev ziyaretleri yoluyla ailelerle görüşmeler gerçekleştirebilir, öğrenci ve ailesi hakkında psikososyal incelemeler yapabilir ve bunları raporlaştırabilir. Bu raporlar özel gereksinimli öğrencinin eğitim süreci boyunca uygulanacak BEP'lerde görev alacak öğretmenlere öğrenci, ailesi ve sosyal çevresi hakkında bilgi sahibi olma ve varsa bu süreçte meydana gelen değişimlerin izlenebilmesi avantajı sağlar.

Özel gereksinimli çocukların eğitimi özen gerektiren bir süreçtir ve Mustafa Kemal Atatürk’ün de dediği gibi: "Eğitimde Feda Edilecek Bir Fert Yoktur". Özel gereksinimli çocukların eğitimi en yüksek kalitede olmalıdır ve bu eğitim sürecine bu çocukların psikososyal ve eğitsel faydasının en yüksek seviyeye ulaştırılmasına katkı sağlayacak bütün profesyonellerin dâhil edilmesi gereklidir. Bu noktada BEP özelinde düşünüldüğünde bu program kapsamında okul sosyal hizmet uzmanlarına ne kadar ihtiyaç duyulduğu aşikârdır.

$\mathrm{Bu}$ araştırma bulgularının ışığında şu önerilerde bulunulabilir:

- Öğretmen adayları, öğretmenler, okul yöneticileri, okul personelleri, aileler ve özel gereksinimli öğrenciler çeşitli eğitim ve seminerlerle alanında uzman kişiler tarafından BEP hakkında bilgilendirilmeli,

- Hazır BEP kullanımına duyulan gereksinim minimuma indirgenmeli,

- Eğitim fakültelerinde BEP'e ilişkin dersler ve konular yoğunlaştırılmalı,

- BEP Geliştirme Birimi üyelerinin birbirleriyle uyum içerisinde çalışabilmesi ve bu birim üyelerinin BEP uygulama sürecine etkin katılımını sağlamak için teşvik ödemeleri ve benzeri uygulamalar olmalı,

- BEP Geliştirme Biriminde yer alan üyelerin psikolojik dayanıklılıklarının artırılabilmesi için eğitim ve uygulamalar düzenlenmeli,

- BEP'in en iyi şekilde uygulanabilmesi için gerekli olan fiziki ortam, zaman ve materyal edinilmesi gibi şartlar maksimum düzeyde sağlanmalı, 
- Hazırlanan ve uygulanan BEP'ler Rehberlik ve Araştırma Merkezleri tarafından düzenli şekilde denetlenmeli,

- BEP'li öğrenciler açısından sosyal uyumun sağlanması ve sosyal dışlanmanın engellenmesi amacıyla okul kapsamında aktiviteler düzenlenmeli,

- Velilerin BEP sürecine aktif katılımı teşvik edilmeli ve BEP sürecine katılımın önündeki engellerin kaldırılmasına yönelik uygulamalar geliştirilmeli,

- Diğer öğrenciler ve velilerin özel gereksinimli öğrenciye yönelik olumsuz tutumlarının önüne geçilmesine yönelik eğitim programları ve uygulamalar geliştirilmeli,

- Okul sosyal hizmeti uygulaması yaygınlaştırılmalı, okul sosyal hizmet uzmanları her okulda istihdam edilmeli ve BEP Geliştirme Biriminin daimi üyesi olmalıdır.

\section{Yazarların katkı oranı beyanı}

Yazarlar makalenin veri toplama, veri analizi, raporlaştırma ve diğer aşamalarından eşit düzeyde sorumlu olduğunu beyan ederler.

\section{Çıkar Çatışması}

Bu çalışmada yazarlar tarafindan herhangi bir çıkar çatışması belirtilmemiştir.

\section{Etik Kurul Onayı}

$\mathrm{Bu}$ araştırma T.C. Karabük Üniversitesi Sosyal ve Beşeri Bilimler Etik Kurulunun 09.04.2021 tarih ve 2021/04-08 kararı ile etik açından uygun bulunmuştur. Tüm sorumluluk yazarına aittir.

\section{Kaynakça}

Akkoyunoğlu, Ö. (2019). Müzik Öğretmenlerinin Bireyselleştirilmiş Eğitim Programı Hazırlamada Karşılaştıkları Güçlüklerin Belirlenmesi ve Kaynaştırma Uygulamalarına İlişkin Görüşlerinin İncelenmesi (Yayımlanmamış Yüksek Lisans Tezi). Atatürk Üniversitesi Eğitim Bilimleri Enstitüsü, Erzurum.

Akyüz, Z. (2018). Ilköğretim Öğretmenlerinde Sosyal Hizmet Algısl ve Okul Sosyal Hizmeti (Yayımlanmamış Yüksek Lisans Tezi). İstanbul Sabahattin Zaim Üniversitesi Sosyal Bilimler Enstitüsü, İstanbul.

Avcıoğlu, H. (2011). Zihinsel Engelliler Sınıf Öğretmenlerinin Bireyselleştirilmiş Eğitim Programı (BEP) Hazırlamaya İlişkin Görüşleri. Ankara Üniversitesi Eğitim Bilimleri Fakültesi Özel Eğitim Dergisi, 12(1), s. 39-53.

Bedur, S., Bilgiç, N. ve Taşlıdere E. (2015). Özel (Üstün) Yetenekli Öğrencilere Sunulan Destek Eğitim Hizmetlerinin Değerlendirilmesi. Hasan Ali Yücel Ĕ̈itim Fakültesi Dergisi, 12-1(23), s. 159-175.

Burunsuz, E. ve İnce, M. (2020). İlköğretim Okullarında Görev Yapan Öğretmenlerin Bireyselleştirilmiş Eğitim Programının Uygulanmasına İliş̧kin Öğretmen Görüşleri. Akdeniz Eğitim Araştırmaları Dergisi, 14(31), s. 530-544.

Camadan, F. (2012). Sınıf Öğretmenleri ve Sınıf Öğretmeni Adaylarının Kaynaştırma Eğitimine ve BEP Hazırlamaya İlişkin Öz-Yeterliliklerinin Belirlenmesi. Elektronik Sosyal Bilimler Dergisi, 11(39), s. 128-138.

Can, B. (2015). Bireyselleştirilmiş Eğitim Programı İle İlgili Özel Eğitim Öğretmenlerinin Yaşadıkları Sorunlar Ve Bu Sorunlara Yönelik Çözüm Önerileri KKTC Örneği (Yayımlanmamış Yüksek lisans tezi). Yakındoğu Üniversitesi Eğitim Bilimleri Enstitüsü, Lefkoșa.

Constable, R. (1999). The Individualized Education Program and the IFSP: Content, Process and the Social Worker's Role. R. Constable, S. McDonald, ve J.P. Flynn (Ed.). School Social Work: Practice, Research, and Policy Perspectives (4. Bask1) içinde (s. 289-306). Chicago: Lyceum Books.

Constable, R. (2009). The Role of the School Social Worker. C. Massat, R. Constable, S. McDonald ve J. P. Flynn (Eds.). School Social Work: Practice, Policy and Research (7. Bask1) içinde (s. 3-29). Chicago: Lyceum Books, Inc.

Creswell, J.W. (2012). Educational Research: Planning, Conducting, and Evaluating Quantitative and Qualitative Research (4. Bask1). Boston: Pearson Education, Inc.

Çıkılı, Y., Gönen, A., Bağcı, Ö. A., ve Kaynar, H. (2020). Özel Eğitim Alanında Görev Yapan Öğretmenlerin Bireyselleştirilmiş Eğitim Programı (Bep) Hazırlama Konusunda Yaşadıkları Güçlükler. OPUS Uluslararası Toplum Araştırmaları Dergisi, 15(1), s. 5121-5148.

Çuhadar, Y. (2006). İlköğretim Okulu 1-5. Sınıflarda Kaynaştırma Eğitimine Tabi Olan Öğrenciler için Bireyselleştirilmiş Eğitim Programlarının Hazırlanması, Uygulanması, İzlenmesi ve Değerlendirilmesi ile İlgili Olarak Sınıf Öğretmenleri ve Yöneticilerin Görüşlerinin Belirlenmesi (Yayımlanmış Yüksek Lisans Tezi). Zonguldak Karaelmas Üniversitesi Sosyal Bilimler Enstitüsü, Zonguldak. 
Debbağ, M. (2017). Opinions of Prospective Classroom Teachers about their Competence for Individualized Education Program (IEP). Universal Journal of Educational Research, 5(2), s. 181-185.

Demirbilek, M. ve Levent, F. (2020). Kaynaştırma Sınıflarında Özel Eğitim Alan Öğrencilere Yönelik Öğretmen Davranışlarına İlişskin Rehberlik Öğretmenlerinin Görüşleri. Ankara Üniversitesi Eğitim Bilimleri Fakültesi Ö̈zel Eğitim Dergisi, 21(3), s. 479-511.

Dupper, D.R. (2003). School Social Work: Skills and Interventions for Effective Practice. Hoboken, NY: John Wiley \& Sons.

EARGED [Milli Eğitim Bakanlığı Eğitimi Araştırma ve Geliştirme Dairesi Başkanlığı] (2010). İlköğretim Okullarındaki Kaynaştırma Uygulamalarının Değerlendirilmesi. https://www.meb.gov.tr/earged/earged/ilk_kaynas_eg_uyg_deg.pdf, Erişim Tarihi: 07.04.2021.

Evyapan, G. (2020). Okul Öncesi Öğretmenlerinin Kaynaştırma Eğitimine İlişkin Öz-Yeterlilik Alg1 Düzeyleri Ve Bireyselleştirilmiş Eğitim Programı Hakkındaki Görüşleri (Yayımlanmamış Yüksek Lisans Tezi). Balıkesir Üniversitesi Sosyal Bilimler Enstitüsü, Balıkesir.

Güleç-Aslan, Y., Özbey, F., Sola-Özgüç, C. ve Cihan, H. (2014). Vaka Araştırması: Özel Eğitim Alanında Çalışan Öğretmenlerin Sorunları ve İhtiyaçları. Uluslararast Sosyal Araştırmalar Dergisi, 7(31), s. 639-654.

ICISD [Ionia Country Indermediate School District] (2015). School Social Work Guidelines, http://ioniaisd.pbworks.com/w/file/fetch/100943845/SSW\%20Guidelines\%20-\%20August\%202015\%20-\%20pdf.pdf, Erişim Tarihi: 16.01.2021.

IDEA Website (2021a). A History of the Individuals With Disabilities Education Act, https://sites.ed.gov/idea/IDEA-History , Erişim Tarihi: 30.03.2021.

IDEA Website (2021b). IDEA Part B Regulations- Assistance to States for the Education of Children with Disabilities, Subpart A- General, Related Services, https://sites.ed.gov/idea/regs/b/a/300.34, Erişim Tarihi: 30.03.2021.

İlik, S. S. (2019). Üstün Yetenekli Öğrencilerin Eğitiminde Görev Yapan Öğretmenlerin Bireyselleştirilmiş Eğitim Programları Hazırlamaya Uygulamaya Ve İzlemeye Yönelik Görüşlerinin Değerlendirilmesi. Kastamonu Eğitim Dergisi, 27(2), s. 485495 .

Kargın, T. (2007). Eğitsel Değerlendirme Ve Bireyselleştirilmiş Eğitim Programı Hazırlama Süreci. Ankara Üniversitesi Eğitim Bilimleri Fakültesi Özel Eğitim Dergisi, 8(1), s. 1-13.

Kesici, A. G. (2019). Bireyselleştirilmiş Eğitim Programı Çerçevesinde Kaynaştırma Eğitimine Devam Eden Zihinsel Engelli Öğrenciler ve Tarih Dersleri (Yayımlanmamış Yüksek Lisans Tezi). Marmara Üniversitesi Eğitim Bilimleri Enstitüsü, İstanbul.

Kopels, S., Rich, M. ve Massat, C.R. (2016). Educational Mandates for Children with Disabilities: School Politicies, Case Law, and School Social Worker. C.R. Massat, M.S. Kelly ve R. Constable (Ed.). School Social Work: Practice, Policy, and Research (8. Bask1) içinde (s. 157-174). USA: Oxford University Press.

Kuli, G. ve Yıldırım, Ş. (2019). Rehberlik Öğretmenlerinin Okul Sosyal Hizmetine İhtiyaç Duydukları Sorun Alanlarının Belirlenmesi. Toplum ve Sosyal Hizmet, 30(2), s. 555-582.

Kuru Habiboğlu, N. (2018). İlkokullarda Çalışan Sınıf Öğretmenlerinin Ve Rehber Öğretmenlerin Bireyselleştirilmiş Eğitim Programı Geliştirme Birimine İlişkin Görüşleri (Yayımlanmamış Yüksek Lisans Tezi). Bolu Abant İzzet Baysal Üniversitesi Eğitim Bilimleri Enstitüsü, Bolu.

Kuyumcu, Z. (2011). Bireyselleştirilmiş Eğitim Planı (BEP) Geliştirilmesi ve Uygulanması Sürecinde Öğretmenlerin Yaşadıkları Sorunlar ve Bu Sorunlara Yönelik Çözüm Önerileri (Yayımlanmamış Yüksek Lisans Tezi). Ankara Üniversitesi Eğitim Bilimleri Enstitüsü, Ankara.

MEB [Milli Eğitim Bakanlığı] (2014). Çocuk Gelişimi ve Eğitimi Özel Eğitim. http://ismek.ibb.gov.tr/ismek-el-sanatlari-kurslari/webedition/file/2016_hbo_program_modulleri/ozelegitim.pdf, Erişim Tarihi: 15.01.2021.

MEB [Milli Eğitim Bakanlığı] (2015). Çocuk Gelişimi ve Eğitimi Özel Eğitimde Plan. http://megep.meb.gov.tr/mte_program_modul/moduller/\%C3\%96zel\%20E\%C4\%9Fitimde\%20Plan.pdf, Erişim Tarihi: 15.01.2021.

NASW [National Association of Social Workers] (2010). Social Workers in Schools (Kindergarten through 12th Grade), https://www.socialworkers.org/LinkClick.aspx?fileticket=vvUJM-JNAEM\%3D\&portalid=0 , Erişim Tarihi: 15.01.2021.

NASW [National Association of Social Workers] (2012). NASW Standards for School Social Work Services, https://www.socialworkers.org/LinkClick.aspx?fileticket=1Ze4-9-Os7E\%3d\&portalid=0 , Erişim Tarihi: 15.01.2021.

NICHCY [National Information Center for Children and Youth with Disabilities] (2000). A Guide to Individualized Education Program, http://www.pluk.org/Pubs/Fed/OSERSiepguide_549k.pdf, Erişim Tarihi: 05.04.2021.

NYC Department of Education (t.y.) Family Guide to Special Education Services. https://www.schools.nyc.gov/docs/defaultsource/default-document-library/family-guide-to-special-education-school-age-services-english , Erişim Tarihi: 16.01.2021.

Openshaw, L. (2008). Social Work in Schools: Principles and Practice. New York: The Guilford Press.

ÖEHY [Özel Eğitim Hizmetleri Yönetmeliği] (2018). T.C. Resmi Gazete, sayı: 30471, 7 Temmuz 2018. 
Özan, S. (2019). Sınıf Öğretmenleri ile Rehberlik ve Psikolojik Danışmanlık Öğretmenlerinin Bireyselleştirilmiş Eğitim Programı Sürecine İlişkin Deneyimleri (Yayımlanmamış Yüksek Lisans Tezi). Dokuz Eylül Üniversitesi Eğitim Bilimleri Enstitüsü, İzmir.

Özel Eğitim Hakkında Kanun Hükmünde Kararname (1997). T.C. Resmi Gazete, sayı: 23011, 6 Haziran 1997.

Öztürk, C. Ç. ve Eratay, E. (2010). Eğitim Uygulama Okuluna Devam Eden Zihin Engelli Öğrencilerin Öğretmenlerinin Bireyselleştirilmiş Eğitim Programı Hakkında Görüşlerinin Belirlenmesi. Abant İzzet Baysal Üniversitesi Eğitim Fakültesi Dergisi, 10(2), s. 145-159.

Patton, M.Q. (2005). Qualitative Research. B. Everitt ve D. Howell, D.C. (Ed.). Encyclopedia of Statistics in Behavioral Science (Cilt 3) içinde (s. 1633-1636). John Wiley\& Sons: Chichester.

Powers, J.D., Swick, D.C. ve Cherry, J.B. (2017). Special Education. L. Villarreal Sosa, T. Cox ve M. Alvarez (Ed.). School Social Work: National Perspectives on Practice in Schools içinde (s. 99-111). NY: Oxford University Press.

Raines, J.C. ve Dibble, N.T. (2017). Ethical and Legal Foundations for School Social Work Practice. L. Villarreal Sosa, T. Cox ve M. Alvarez (Ed.). School Social Work: National Perspectives on Practice in Schools içinde (s. 113-132). NY: Oxford University Press.

Ritter, J.A. ve Ofahengaue Vakalahi, H.F. (2015). 101 Careers in Social Work (2. Bask1). NY: Springer Publishing Company.

Santos, M., Duman, B., Yıldırım Erişkin, A., Coşgun Başar, M. ve Kıraç, S. (2012). Individualized Education Program (IEP) (Modül 5). M. Santos (Ed.). Cerebral Palsy Trainee Booklet for Parents and Teachers: Development of Supportive Packages for Parents and Teachers of Children with Cerebral Palsy (03-18 Age Group) içinde (s. 91-115). Ankara: Pozitif Matbaas1.

Sevim, O., Kayman, F. ve Kaya, M. (2021). Türkçe Öğretmenlerinin Bireyselleştirilmiş Eğitim Programının (BEP) Uygulanabilirliği Hakkındaki Görüşleri. International Journal of Language Academy, 9(1), s. 159-174.

Siegel, M. L. (2005). Nolo’s IEP Guide Learning Disabilities (2.Bask1). USA: Nolo.

Silverman, D. (2021). Introducing Qualitative Research. D. Silverman (Ed.). Qualitative Research (5. Bask1) içinde (s. 3-16). SAGE: London.

Smith, S. W. ve Brownell, M. T. (1995). Individualized Education Programs: Considering the Broad Context for Reform. Focus on Exceptional Children, 28(1), s. 1-12.

SSWAA [School Social Work Association of America] (2021). Role of School Social Worker, https://www.sswaa.org/schoolsocial-work , Erişim Tarihi: 15.01.2021.

Şahin, A. ve Gürler, B. (2018). Destek Eğitim Odasında ve Kaynaştırma Ortamlarında Çalışan Öğretmenlerin Bireyselleştirilmiş Eğitim Programı Hazırlama Sürecinde Yaşadıkları Güçlüklerin Belirlenmesi. Adıyaman Üniversitesi Sosyal Bilimler Enstitüsü Dergisi, 29, s. 594- 625.

Taşdemir, M., Taşdemir, F., Keskinkılıç, V., Köksal, A.C. ve Şahin, C. (2017). Bireyselleştirilmiş Eğitim Programları Üzerine Bir Durum Çalışması: Kırşehir ili Örneği. Eğitim ve Öğretim Araştırmaları Dergisi, 6(3), s. 199-209.

Tekin Ersan, D. ve Ata, S. (2017). Okul Öncesi Öğretmenlerinin Bireyselleştirilmiş Eğitim Programı Hazırlanmasına İlişkin Görüşleri. Trakya Üniversitesi Ĕgitim Fakültesi Dergisi, 8(1) (USOS Özel Sayısı), s. 162-177.

Toprak, Ö.F. (2018). Bireyselleştirilmiş Eğitim Programı Hazırlama Sürecine İlişkin Ekip Üyelerinin Deneyimleri: Bir Ortaokul Örneği (Yayımlanmamış Yüksek Lisans Tezi). Anadolu Üniversitesi Eğitim Bilimleri Enstitüsü, Eskişehir.

Vuran, S., Bozkuş-Genç, G. ve Sani-Bozkurt, S. (2017). İşbirliği İle Bireyselleştirilmiş Eğitim Programı Geliştirme Süreci: Durum Çalışması. Ankara Üniversitesi Eğitim Bilimleri Fakültesi Özel Eğitim Dergisi, 18(02), s. 165-184.

Washington State Department of Social and Health Services (2010). Social Worker's Practice Guide to Education for Children and Youth in Foster Care. https://www.dshs.wa.gov/sites/default/files/publications/documents/22-1185.pdf, Erişim Tarihi: 16.01.2021.

Yaman, A. (2017). Kaynaştırma Modeli ile Eğitilen Öğrenciler için Bireyselleştirilmiş Eğitim Programlarının Geliştirilmesi ve Uygulanmasına Yönelik Sınıf Öğretmenlerinin Görüşlerinin Belirlenmesi (Yayımlanmamış Yüksek Lisans Tezi). Necmettin Erbakan Üniversitesi Eğitim Bilimleri Enstitüsü, Konya.

Yazıcıoğlu, T. (2019). Rehberlik Öğretmenlerinin Bireyselleştirilmiş Eğitim Programı (BEP) Biriminin İşleyişine İlişkin Görüşleri. Anemon Muş Alparslan Üniversitesi Sosyal Bilimler Dergisi, 7(5), s. 223-234.

Yıldırım, A. ve Şimşek, H. (2013). Sosyal Bilimlerde Nitel Araştırma Yöntemleri (9. Baskı). Ankara: Seçkin Yayıncılık.

Yılmaz, E. ve Batu, S. E. (2016). Farklı Branştan İlkokul Öğretmenlerinin Bireyselleştirilmiş Eğitim Programı, Yasal Düzenlemeler ve Kaynaştırma Uygulamaları Hakkındaki Görüşleri. Ankara Üniversitesi Eğitim Bilimleri Fakültesi Özel Eğitim Dergisi, 17(3), s. 247-268. 


\section{Extended Abstract}

Individuals may not have the same features in terms of physical structure, intelligence level, ability, emotion and thinking. Due to these differences, individuals with special needs have the right to education like other individuals. Equality of opportunity is tried to be achieved with special education and the education of disabled students is organized.

In order for students with special needs not to fall behind education, their education should be individualized. Also students with the same disability may have different needs. Individualized Education Program (IEP) is one of the special education methods developed for students with special needs. IEP is an education program for students with special needs, prepared by taking into account the individual characteristics and needs of the student. IEPs, which are a report showing the place, time, duration and by whom the student's education will be applied, fulfill the academic and social needs of the students. With IEP, it is aimed to meet the needs of students in both private and general education classes.

This program has different benefits for students, families, teachers and society. For the application of IEP in the school or institution where the student is studying IEP Development Units are established. In this unit, there are a guidance counselor, the student's class teacher, the related field teachers who teach the student's course, the student's parent and the student. School or institution management determines the working procedures and principles of the unit. The unit works in cooperation.

Special education was organized in the United States of America with the Education Act for All Disabled Children (EHA) enacted in 1975. This law has been revised many times and finally its name has been determined as the Individuals with Disabilities Education Act (IDEA). IEPs are an important part of this law. In Turkey, IEPs have become mandatory with the Decree Law No. 573 issued in 1997. In the following years, IEPs were also regulated and updated in the Special Education Services Regulations in 2000, 2006, 2012, 2018.

School social work is a professional discipline that aims to increase students' psychosocial well-being and academic success. In order to achieve these goals, school social workers determine the needs of the student in a realistic way by evaluating the student within the framework of the "individual within his/ her environment" understanding and undertake various roles to meet these needs.

This research is a qualitative study designed to evaluate teachers 'opinions on IEP and school social work, and to include teachers' opinions on the roles that school social workers can undertake by taking part in this program. In this study, the snowball sampling method, which is one of the purposeful sampling methods, was used to determine the study group. In order to obtain the data composing the research, a total of 11 teachers, 8 male and 3 females, were interviewed. Teachers are people who live in Karabük and have applied IEP at least once in their professional life. Participants in the study were coded as Ö1, Ö2, Ö3... Ö11 in order to ensure the confidentiality of the research. After the relevant literature review, data were collected by creating a semi-structured interview form in order to collect data. The semi-structured interview form used includes 6 personal information questions and 5 open-ended questions. Descriptive and thematic analysis methods were used to analyze the collected data. Themes were created according to the answers given and some opinions were given by direct quotation.

Within the scope of the research, the participants were asked to define the IEP. According to the answers given, it was seen that the participants were able to define IEP and have information about IEP. Participants stated that they found IEP to be useful and necessary in their IEP opinions.

Participants were asked to evaluate the advantages and disadvantages of IEP. According to the participants IEP has got advantages such as preparation according to a child with special needs, increasing the self-confidence of the student and ensuring the adaptation of the student to the school. The disadvantages of IEP according to the participants are that there are people who act prejudicially against the student to whom IEP is applied, the student does not attend the program continuously, the student isolates herself/himself from other students, and other students exclude the student who is applied IEP. There were also participants who stated that IEP has no disadvantage.

In the context of IEP, school social workers act as a bridge between the school and the family concerning communication and cooperation with parents with whom teachers experience the most problems while applying IEP. To determine the factors that affect the success of the student with special needs, it collects information about these factors by evaluating the student and his/her environment. It undertakes roles such as advocacy, consultancy and policy development for the solution of factors that negatively affect student success. In addition, school social workers make important contributions to the most effective applying of IEP. 
School social work is widely practiced in many countries and in these countries school social workers are included in IEP application teams. The position and roles of school social workers in IEP applications are also supported by laws and application regulations (IDEA Website, 2021a; IDEA Website, 2021b). However, in our country, school social work remained at the project stage. This situation has caused that school social workers are not included in the IEP Development Unit in the Special Education Services Regulation and school social workers cannot be included in the IEP application teams (ÖEHY, 2018).

When teachers are applying IEP, students (e.g., disability type, personal characteristics and communication skills of the student), parents (e.g., their inability to accept their child's disability, high expectations about the child, not cooperating) and school-related (e.g. lack of time, the lack of material, inconvenience of classroom environments) stated that they experienced difficulties.

Teachers stated facilitated the applying of IEP that the correct determination of the academic and mental level of the student, the preparation of the IEP to meet the needs of the student, the lack of intensive course programs, the absence of the student's absenteeism and the cooperation with the family. Again, according to teachers, makes it difficult to applying of IEP, factors such as lack of communication and cooperation with parents, parents' inability to accept the disability of their children, absenteeism, lack of information about IEP, use of ready-made IEP, lack of material and students with special needs not being accepted at school.

According to the findings, most of the teachers are knowledgeable about the field of social work. The fields where they have the most information are family, children, disabled and elderly fields. It has been observed that although the teachers have information about social work field, they do not have information about school social work. However, teachers think that social workers should be in schools and that school social workers can contribute to the applicability of IEP, providing school-family cooperation, providing counseling services to families, evaluating the student and their family, and meeting the needs of students with special needs.

According to the results of this study, teacher candidates, teachers, school administrators, school staff, families and students with special needs should be informed about IEP by experts in their fields through various trainings and seminars. In order to meet the psychosocial and educational needs of children with special needs, professionals who will contribute to this process should be included in the special education process. School social work should be made widespread both in order to meet the needs of all students in schools and to implement this program more effectively in terms of IEP. School social workers should be employed and become permanent members of the IEP Development Unit. 